\title{
Analisis Peramalan Dan Perencanaan Penjualan Buku Lks Dalam Upaya Meningkatkan Kebutuhan Produk Dengan Menggunakan Metode Least Square Dan Anova
}

\author{
Estiningsih Trihandayani ${ }^{1}$, Sri Utaminingsih ${ }^{2}$ \\ ${ }^{1)}$ Teknik Industri Fakultas Teknik Universitas Pamulang, Tangerang Selatan Banten 15417, Indonesia, \\ ${ }^{2)}$ Pendidikan Pancasila Dan Kewarganegaraan, Universitas Pamulang, Tangerang Selatan Banten 15417, \\ dosen00311@unpam.ac.id
}

\begin{abstract}
ABSTRAK
Untuk memenuhi permintaan buku ke percetakan CV. Dunia Pustaka pada semester satu dan semester dua untuk 5 tahun kedepan adalah dari tahun 2017-2022 adalah 133.570 examplar, 134.001 examplar, 134,432 examplar, 134.862 examplar, 135.292 examplar.Untuk hipotesis anova dua jalur tanpa interaksi ini pernyataan, karena nilai $F_{1}$ hitung $=7.746,9>4,10$ maka $F_{1}$ hitung $>$ dari Ftabel artinya ada perbedaan rata-rata penjualan buku dari tiap kota tersebut dalam 5 tahun. Dalam hal ini berarti HO di tolak di karenakan ada perbedaan penjualan tiap kota dalam 5 tahun. Kota Pandeglang: Jika -thitung < -ttabel maka ada perbedaan volume penjualan dalam 5 tahun antara sebelum dan sesudah melakukan peramalan. Ternyata: -31,809 < - 2,776, maka H0 di tolak. Kota Serang: Jikathitung $<$-tabel maka ada perbedaan volume penjualan dalam 5 tahun antara sebelum dan sesudah melakukan peramalan, Ternyata: -49,685 < - 2,776, maka HO di tolak Kota Cilegon : Jika thitung < ttabel ada perbedaan volume penjualan dalam 5 tahun antara sebelum melakukan peramalan dan sesudah peramalan. Ternyata: $-63.478<-2,776$, maka $\mathrm{HO}$ di tolak. Dalam hal ini hasilnya minus maka dalam salah satu tahun sebelum atau sesudah peramalan forcastingnya lebih kecil, dan dikarenakan data yang dioleh memiliki nilai yang besar maka hasil thitung pun besar nilainya.
\end{abstract}

Kata Kunci : F Hitung, Anova, Least Square, Hipotesis

\section{PENDAHULUAN}

Setiap perusahaan memiliki tujuan menghasilkan produk atapun jasa yang menjadi keperluan pelanggan dan juga untuk mendapatkan keuntungan dari usaha tersebut. Perusahaan mempunyai pandangan supaya pada masa yang akan datang mendapatkan perubahan, yang dimaksud perubahan di sini adalah perubahan ke arah yang lebih baik atau bisa dikatakan mengalami perkembangan. Ada beberapa cara dalam mewujudkan perkembangan untuk perusahaan salah satunya adalah membuat kebijakan untuk mendapatkan solusi untuk permasalahan di perusahaan.

CV. Mandiri Berkah sebagai distributor buku, yang telah memiliki kepercayaan dalam pendistribusian buku yaitu buku untuk memudahkan tenaga pengajar dalam melakukan kegiatan belajar mengajar pada setiap sekolah. Pada penelitian ini penulis menelitipada produk LKS ( Lihat Lampiran 2). Dalam memenuhi permintaan sekolah pada buku LKS yang akan di disitribusikan tentunya perusahaan bekerja sama dengan percetakan.
Ada banyak percetakan yang bekerja sama dengan CV. Mandiri Berkah salah satunya CV. Dunia Pustaka di karenakan bahan ajar pada buku yang di cetak lengkap sesuai dengan kriteria sekolah sehingga hal tersebut membuat permintaan buku cukup banyak. Dalam data penjualan ini terlihat kenaikan yang terus menerus. Maka dari itu kita dapat mengetahui data historis penjualan buku LKS sehingga memudahkan peneliti untuk menentukan metode yang tepat dalam melakukan peramalan pada produk LKS untuk periode penjualan yang akan datang dan hal tersebut terlihat dari Grafik penjualan yang selalu meningkat dari tahun ke tahun, dapat di lihat pada Gambar 1.1.

\section{Grafik Penjualan dan Permintaan}

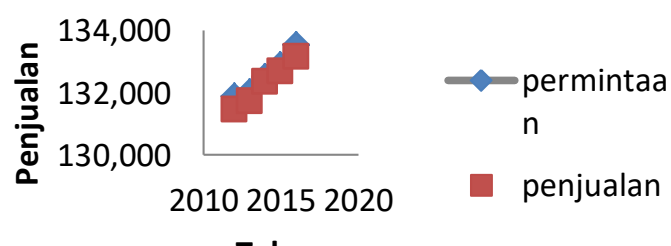

Tahun 
Gambar 1.1 Garis Trend Penjualan buku LKS (Sumber: data CV. Mandiri Berkah)

Dari data penjualan di atas bahwa terjadi kenaikan pada setiap tahun dalam dua semester. Hal tesebut berpengaruh terhadap CV. Mandiri Berkah karena tidak memiliki perhitungan yang tepat dalam meramalkan penjualan pada beberapa tahun kedepan, di karenakan penjualan lebih lebih sedikit dibanding permintaan sehingga masih banyak yang tidak terlayani. Saat ini CV. Mandiri Berkah belum melakukan peramalan permintaan secara efektif dan efisien dalam menentukan target penjualan.

Dalam bisnis ini banyak perusahaan yang menjalani bisnis yang sama, sehingga persaingan usaha dalam bidang pendistribusian ini semakin ketat. Hal tersebut dapat di dasarkan kepada permintaan buku LKS (Lihat Lampiran 1), yang acuanya kepada jumlah siswa dari masing- masing sekolah dalam tiga kota yaitu kota Pandeglang, Serang, dan Cilegon, yang sudah bekerja sama dengan CV. Mandiri Berkah.

Dalam hal pendistribusian khususnya untuk tingkat SMP, CV. Mandiri Berkah melihat permintaan buku karena dibandingkan tingkat SD dan SLTA, tingkat permintaan buku LKS SMP sangat banyak pada setiap semesternya, terkadang permintaanya meningkat tapi perusahaan tidak bisa memenuhi keinginan sekolah dikarenakan stok di gudang kurang atau tidak ada. Atau masalah selanjutnya karena tidak ingin terjadi penumpukan buku yang terlalu banyak maka perusahaan memesan buku kepada percetakan sesuai permintaan sekolah, hal ini menimbulkan banyak permasalahan selain karena pelayanan perusahaan kepada konsumen tidak memuaskan juga menyebabkan biaya yang lebih banyak karena untuk pengambilan buku ke percetakan tentunya membutuhkan waktu dan biaya juga bisa saja percetakan tidak bisa memenuhi order dari perusahaan CV. Mandiri Berkah.

Dalam hal ini dilakukan peramalan dengan menggunakan metode Least Square Test, peramalan dengan menggunakan metode ini sangat efektif karena tingkat kesalahan peramalannya sangat kecil dan data penjualan yang cenderung mengikuti pola trend yaitu peningkatan yang terus menerus setiap tahun, dan selanjutnya menggunakan uji Anova, dan pengujian yang dipilih adalah uji Anova dua jalur tanpa interaksi yang digunakan untuk mengetahui perbedaan rata-rata jumlah penjualan buku setiap tahun dari beberapa kota. Dan perbedaan rata-rata penjualan setiap kota dalam beberapa tahun agar dapat mengetahui signifikasi penjualan karena akan mudah jika kita dapat mengetahui signifikasi penjualan. Dan setelah melakukan peramalan dengan menggunakan metode tersebut untuk langkah selanjutnya dilakukan uji paired sample $t$ test untuk mengetahui signifikasi perbedaan penjualan sebelum dan sesudah forcasting..

\section{DASAR TEORI}

Peramalan dapat dibedakan menjadi dua jenis, Yaitu:

1. Dilihat dari Sifat Penyusunannya.
a. Peramalan subjektif,
b. Peramalan yang objektif

2. Dilihat dari Jangka Waktu peramalan yang Disusun
a. Peramalan jangka pendek.
b. Peramalan jangka menengah.
c. Peramalan jangka Panjang.

3. Berdasarkan sifat ramalan yang telah disusun, maka peramalan dapat dibedakan atas dua jenis :

a. Peramalan Kualitatif

Yaitu peramalan yang didasarkan atas kualitatif pada masa lalu.

b. Peramalan Kuantitatif

Yaitu peramalan yang didasarkan atas data kuntitatif pada masa lalu. Peramalan kuantitatif hanya dapat digunakan apabila terdapat tiga kondisi sebagai berikut:

1) Adanya informasi tentang keadaan yang lain.

2) Informasi tersebut dapat dikuantifikasikan dalam bentuk data.

3) Dapat diasumsikan bahwa pola yang lalu akan berkelanjutan pada masa yang akan datang.

Faktor Mempengaruhi Pemilhan Teknik Peramalan

Faktor yang harus dipertimbangkan:

1. Horizon Peramalan

2. Ada dua aspek dari horison waktu: 
a. Cakupan waktu dimasa yang akan datang

b. Jumlah periode untuk peramalan diinginkan

3. Tingkat Ketelitian

4. Ketersediaan Data.

5. Jenis Pola Data

6. Biaya.

7. Macam-macam model

8. Mudah tidaknya penggunaan dan aplikasinya

\section{Metode Kulitatif.}

Peramalan kualitatif umumnya bersifat subjektif, dipengaruhi oleh intuisi, emosi, pendidikan, dan pengalaman seseorang.

1. Metode Delphi

Tahapan yang dilakukan adalah:

a. Tentukan beberapa ahli sebagai partisipan..

b. Melalui kuesioner (atau email).

c. Simpulkan hasilnya..

d. Simpulkan kembali revisi peramalan dan kondisi.

e. Apabila diperlukan, ulangi tahap 4 Seluruh hasil akhir didistribusikan kepada seluruh partisipan.

2. Pendugaan Managment.

Atau Panel Consensus, dimana peramalan semata-mata berdasarkan pertimbangan manajemen, biasanya oleh manajemen senior.

3. Analisa Pasarr.

Ialah Teknik peramalan berdasarkan hasil dari survei pasar yang dilakukan oleh tenag pemasar barang atau yang mewakilinya.

4. Metode kelompok terstruktur.

Seperti metode Delphi, dan lain lain. Metode Delphi merupakan teknik peramalan berdasarkan pada proses konvergensi dari opini beberapa orang atau ahli secara interaktif tanpa menyebutkan identitasnya.

5. Analogi historis.

Merupakan teknik peramalan berdasarkan pola data masa lalu dari produk-produk yang dapat disamakan secara Analogi.

\section{Teknik Peramalan Kuantitatif.}

Pada dasarnya metoda peramalan kuantitatif ini dapat dibedakan atas dua bagian, yaitu:
1. Metoda peramalan yang didasarkan atas penggunaan analisa pola hubungan antara variabel yang akan diperkirakan dengan variabel waktu, yang merupakan deret waktu atau "time series".

2. Metoda peramalan yang didasarkan atas penggunaan analisa pola hubungan antara variable yang akan diperkirakan dengan variabel lain yang mempengaruhinya, yang bukan waktu yang disebut metode korelasi atau sebab akibat (causal method). Prosedur umum yang digunakan dalam peramalan secara kuantitatif adalah:

a. Definisikan tujuan peramalan.

b. Pembuatan diagram pencar.

c. Pilih minimal dua metode peramalan yang dianggap sesuai.

d. Hitung parameter - parameter fungsi peramalan.

e. Hitung kesalahan setiap metode peramalan.

f. Pilih metode yang terbaik, yaitu yang memiliki kesalahan terkecil.

g. Lakukan verifikasi peramalan.

Dikarenakan dalam penelitian ini menggunakan data yang berhubungan antara variabel dan yag akan di perkirakan dan variabel waktunya maka menggunakan metode Time Series. Metode time series adalah metode yang dipergunakan untuk menganalisis serangkaian data yang merupakan fungsi dari waktu. Metode ini mengasumsikan beberapa pola atau kombinasi pola selalu berulang sepanjang waktu, dan pola dasarnya dapat diidentifikasi semata-mata atas dasar data historis dari serial itu.

Ada empat komponen utama yang mempengaruhi analisis ini, yaitu :

1. Pola Trend

Pola trend bila data permintaan menunjukan pola kecendrungan gerakan penurunan atau kenaikan jangka panjang.
a. Metoda Regresi Linier
b. Exponential Smoothing atau
c. Double Exponential Smoothing 


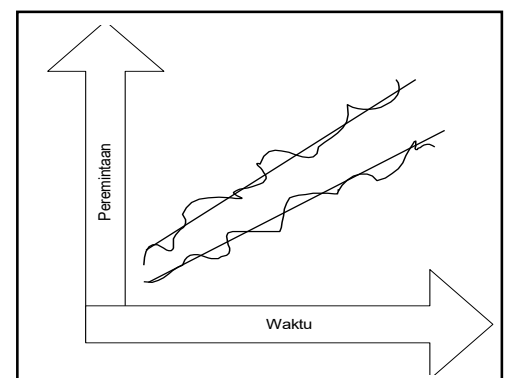

Gambar 2.1. Pola Permintaan Trend

Rumus proyeksi trend dengan metode kuadrat terkecil

dengan :

$$
\bar{y}=a+b x
$$

$\overline{\mathrm{y}}=$ Jumlah Peramalan Produksi.

$\mathrm{a}=$ Nilai ramalan rata-rata produksi.

$\mathrm{b}=$ koefisisen kecondongan garis trend

$\mathrm{x}=$ waktu dalam triwulan

mencari nilai $\mathrm{a}$ dan $\mathrm{b}$ untuk proyeksi trend dengan metode kuadrat terkecil:

Rumus :

$$
\mathrm{a}=\frac{\sum y}{n} \quad \mathrm{dan} \quad \mathrm{b}=\frac{\sum x y}{\sum x^{2}}
$$

2. Pola Musiman

Bila data yang kelihatannya berfluktuasi, namun fluktuasi tersebut akan terlihat berulang dalam suatu interval waktu tertentu, maka data tersebut berpola musimam.
a. Metoda Winter (sangat sesuai)
b. Moving Average
c. Weight Moving Average

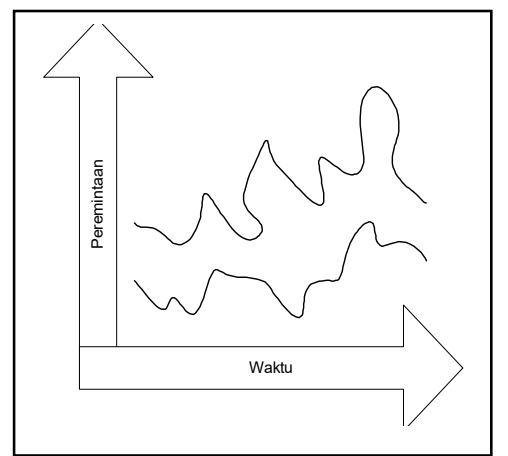

Gambar 2.2. Pola Permintaan Musiman

3. Pola Siklikal

Pola siklikal adalah bila fluktuasi permintaan secara jangka panjang membentuk pola sinusoid atau gelombang atau siklus. Pola siklikal bentuknya selalu mirip gelombang sinusoid. a. Moving Average

b. Weight Moving Average dan

c. Eksponential Smoothing

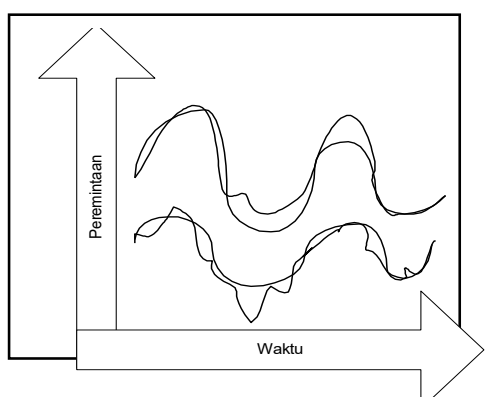

Gambar 2.3. Pola Permintaan Siklikal

4. Pola Eratik/Random

Pola eratik adalah bila fluktuasi data permintaan dalam jangka panjang tidak dapat digambarkan oleh ketiga pola lainnya.

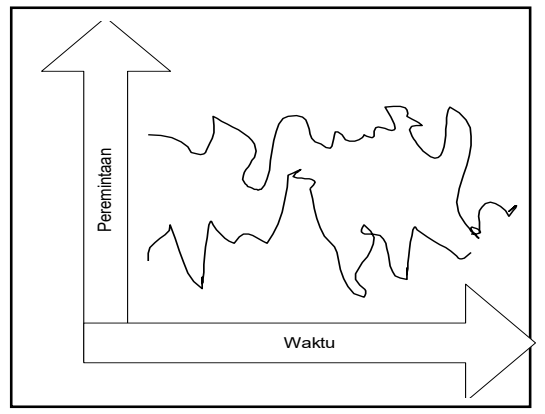

Gambar 2.1. Pola Permintaan Eratik/Random

\subsubsection{Pengertian Analisis Trend}

Analisis trend merupakan suatu metode analisis statistika yang ditujukan untuk melakukan suatu estimasi atau peramalan pada masa yang akan datang.

Sebaliknya, jika data yang dikumpulkan semakin sedikit maka hasil estimasi atau peramalannya akan semakin jelek. Berdasarkan data masa lalu yang akan di jadikan dasar perhitungan dimana data tersebut menunjukan pola kenaikan penjualan setiap tahunnya yang dapat di perhatikan dari garis trend positif karena cenderung naik maka metode yang di gunakan dalam pembahasan penelitian tentang penjualan buku LKS (lembar kerja siswa) ini adalah metode least square.

Sebagai salah satu upaya mencerdaskan kehidupan bangsa sudah seharusnya buku menjadi salah satu hal yang penting bagi para pelajar yang siap menata masa depan yang cerah dan menjadi generasi yang 
membanggakan bangsa. Maka dari itu CV. Mandiri Berkah sebagai distributor buku akan memudahkan tenaga pengajar untuk melakukan kegiatan belajar mengajar pada setiap sekolah. CV. Mandiri Berkah didirikan oleh seorang pengusaha yang sudah menekuni dunia pendidikan dan bisnis, sudah memiliki pengalaman dalam bisnis pendistribusian buku pelajaran khususnya dalam dunia pendidikan, untuk dunia pendidikan,jauh sebelum perusahaan di dirikan pemilik CV.Mandiri Berkah ini seorang guru di sebuah sekolah swasta di Kab. Lebak. Dan memtuskan berhenti dari sekolah tersebut dan tinggal di kota Serang. Dan bekerja di sebuah perusahan sebagai Manager yang mengurusi pendistribusian buku ke sekolah yang ada di kota serang, kabupaten serang,kabupaten cilegon, dan kabupaten lebak.

Semua yang dilakukan pemilik CV.Mandiri Berkah hanya untuk membuka usaha sendiri mengingat usaha di bidang distribusi ini sangat berpeluang besar. Dalam menjalankan usahanya pemilik melakukan penawaran ke setiap sekolah yang berada di Kota Serang, dan Kota Cilegon,dan Kabupaten Lebak, dengan cara menjelaskan beberapa contoh buku serta laba yang didapat oleh sekolah yang mau bekerja sama dengan perusahaanya.

Permintaan buku LKS (lembar kerja siswa) sangat banyak, seiring tingginya jumlah siswa di dunia pendidikan. tetapi di sisi lain daya beli setiap sekolah tergantung kepada siswa siswi, maka dari itu sekolah harus lebih membimbing dan memberikan arahan kepada murid muridnya untuk lebih menggemari membaca buku untuk masa depan mereka. Dengan demikian distributor akan mendapatkan keuntungan dalam pemasaran dan sekolah pun selain mendapat laba dari hasil penjualan buku juga dapat memiliki murid-murid yang berkualitas.

Beranjak dari latar belakang pemikiran inilah akhirnya para penerbit dan distributor merubah strategi pemasarannya dengan melancarkan penjualan dengan ketentuan dan tempo yang di tentukan atas kesepakatan kedua belah pihak, untuk meraih pangsa pasar golongan menengah kepada tahun pertama beroperasi, CV.Mandiri Berkah melaksanakan aktivitasnya dari sebuah perumahan komplek Griya Serang Asri sebagai kantor CV.
Bukan hanya kepada sekolah yang telah menjadi taget pemasaran namun dengan cara menerima freelance dari orang yang ingin bergabung untuk memperluas pemasaran selain itu banyak promosi lain untuk sistem pelayanan yang memuaskan dan menjadikan pelanggan tetap melakukan order di $\mathrm{CV}$. Mandiri Berkah. Demikian juga seluruh karyawan dalam bagiannya dapat menambah kemampuannya dalam mempromosikan atau memasarkan buku aga lebih banyak yang memesan buku di CV.Mandiri Berkah. Penelitian para pengamat pendidikan melihat prospek yang kuat dalam kebutuhan sekolah akan buku pelajaran untuk generasi muda penerus bangsa yang cerah dan cerdas, meskipun situasi pendidikan di indonesia kurang begitu baik, namun dengan adanya para distributor yang senantiasa memudahkan para pengajar dalam memberikan pengajaran pada murid muridnya akan menjadi jalan yang terang bagi kualitas pendidikan Indonesia karena dengan membaca kita senantiasa dapat membuka jendela hidup yang lebih luas, dan memberikan prospek semakin cerah di Indonesia di masa yang akan datang.

\section{METODOLOGI PENELITIAN}

Berdasarkan hasil pengumpulan data, maka dapat dilakukan perhitungan atau pengolahan data baik itu perhitungan atau pengolahan data secara manual dan komputerisasi.

1. Pengolahan Data Secara Manual

Pengolahan data yang dilakukan secara manual adalah perhitungan dari metode Least Square, Anova dua jalur tanpa interaksi dan perhitungan manual dari Paired Sample t test. Pada data penjualan 5 tahun sebelumnya pada CV. Mandiri Berkah.

2. Pengolahan Data Secara komputerisasi Pengolahan data secara komputerisasi dilakukan pada uji paired sample $t T$ test melalui tahapan atau langkah-langkah tertentu.

\section{HASIL DAN PEMBAHASAN}

Berdasarkan data yang didapat di CV. Mandiri Berkah adalah jumlah penjualan buku LKS tingkat SMP (Sekolah Menengah Pertama) dari ketiga kota yaitu kota 
Pandeglang, Serang dan Cilegon dari tahun 2012-2016 dapat di lihat pada Tabel 4.1 berikut ini:

Tabel 4.1 Data Penjualan Buku LKS untuk setiap kota pada Tahun 2012-2016

\begin{tabular}{|c|c|c|c|}
\hline \multirow{2}{*}{ Tahun } & \multicolumn{3}{|c|}{ Kota Pendistribusian } \\
\cline { 2 - 4 } & $\begin{array}{c}\text { Pandegla } \\
\text { ng }\end{array}$ & Serang & Cilegon \\
\hline 2012 & 48.113 & 42.629 & 40.727 \\
\hline 2013 & 48.185 & 42.718 & 40.833 \\
\hline 2014 & 48.299 & 43.002 & 41.040 \\
\hline 2015 & 48.319 & 43.222 & 41.150 \\
\hline 2016 & 48.487 & 43.389 & 41.270 \\
\hline
\end{tabular}

(Sumber: CV. Mandiri Berkah)

penulis ingin meramalkan besarnya tingkat penjualan pada tahun berikutnya dengan mengunakan peramalan Least Square dan untuk mengetahui signifikasi atau perbedaan penjualan pada tiga kota tersebut dalam beberapa tahun akan di hitung dengan uji anova dua jalur tanpa interaksi dan untuk pengujian signifikasi peramalan data penjualan 5 tahun sebelum di lakukan peramalan dan sesudah di lakukan permalan akan di uji menggunakan paired sample $t$ test. Beberapa perhitungan tersebut memerlukan data penjualan lima tahun sebelumnya pada setiap semester yaitu semester satu dan dua. Dalam hal ini dijelaskan bahwa setiap satu semester itu adalah enam bulan. Dalam hal meramalkan suatu penjualan CV. Mandiri Berkah memiliki data beberapa sekolah di tingkat SMP dengan mengetahui jumlah murid dari sekolah yang bekerja sama dengan perusahaan. sekolah yang bergabung dengan perusahaan termasuk sekolah yang unggulan dikotanya.

Seperti yang kita telah ketahui tujuan peramalan dalam penelitian ini adalah untuk menentukan penjualan pada tahun berikutnya sehingga memudahkan order pada percetakan.

\subsubsection{Data Perhitungan dan Peramalan Kota Pandeglang, Kota Serang, dan Kota Cilegon}

Tabel 4.2 Data Penjualan Buku LKS Untuk Kota Pandeglang Tahun 2012-2016

\begin{tabular}{|c|c|c|c|}
\hline Tahun & $\begin{array}{c}\text { Semester } \\
\text { I }\end{array}$ & $\begin{array}{c}\text { Semester } \\
\text { II }\end{array}$ & Jumlah \\
\hline $2012-$ & 24.099 & 24.014 & 48.113 \\
\hline
\end{tabular}

\begin{tabular}{|c|c|c|c|}
2013 & & & \\
\hline $\begin{array}{c}2013- \\
2014\end{array}$ & 24.130 & 24.055 & 48.185 \\
\hline $\begin{array}{c}2014- \\
2015\end{array}$ & 24.154 & 24.149 & 48.299 \\
\hline $\begin{array}{c}2015- \\
2016\end{array}$ & 24.124 & 24.195 & 48.319 \\
\hline $\begin{array}{c}2016- \\
2017\end{array}$ & 24.205 & 24.282 & 48.487 \\
\hline
\end{tabular}

(Sumber: CV. Mandiri Berkah)

Dari data di atas dapat dilihat data penjualan buku LKS tingkat SMP berdasarkan semester satu dan semester dua untuk kota Pandeglang. Dibawah ini hasil penjualan buku untuk tingkat SMP pada kota Serang. Dapat dilihat pada Tabel 4.3 berikut ini:

Tabel 4.3 Data penjualan Buku LKS Untuk Kota Serang pada Tahun 20122016

\begin{tabular}{|c|c|c|c|}
\hline Tahun & $\begin{array}{c}\text { Semester } \\
\text { I }\end{array}$ & $\begin{array}{c}\text { Semester } \\
\text { II }\end{array}$ & $\begin{array}{c}\text { Penjualan } \\
\text { (Examplar) }\end{array}$ \\
\hline $2012-2013$ & 21.316 & 21.313 & 42.629 \\
\hline $2013-2014$ & 21.318 & 21.400 & 42.718 \\
\hline $2014-2015$ & 21.423 & 21.579 & 43.002 \\
\hline $2015-2016$ & 21.578 & 21.644 & 43.222 \\
\hline $2016-2017$ & 21.621 & 21.768 & 43.389 \\
\hline
\end{tabular}

(Sumber: CV. Mandiri Berkah)

Dan data penjualan untuk kota Cilegon dapat kita lihat pada Table 4.4 berikut:

Tabel 4.4 Data penjualan Buku LKS Untuk Kota Cilegon pada Tahun 20122016

\begin{tabular}{|c|c|c|c|}
\hline Tahun & $\begin{array}{c}\text { Semester } \\
\text { I }\end{array}$ & $\begin{array}{c}\text { Semester } \\
\text { II }\end{array}$ & Penjualan \\
(examplar)
\end{tabular}

(Sumber: CV. Mandiri Berkah)

kemudian untuk mencari nilai $\sum Y, \sum X Y$, dan $\sum X^{2}$. Dan di bawah ini dapat juga di lihat perhitungan trend. Dalam menentukan nilai $\mathrm{x} /$ $\mathrm{t}$ seringkali digunakan teknik alternatif dengan memberikan skor atau kode. Dalam Metode Least Square dilakukan pembagian data menjadi dua kelompok, yaitu : 
a. Data genap, maka skor nilai t nya : ..., -5 , $3,-1,1,3,5, \ldots$

b. Data ganjil, maka skor nilai t nya : ..., $-3,-2$ $,-1,0,1,2,3, \ldots$

Dalam penelitian ini data yang akan di oleh termasuk kedalam data ganjil, penjualan yang sesuai dengan trend disebutkan bahwa $\mathrm{Y}$ menerangkan variabel penjualan, dan $X$ melambangkan waktu sedangkan Origin atau di sebut tahun dimana $X=0$ yaitu pada tahun 2014 maka dari itu seperti yang kita ketahui jumlah nilai variabel waktu adalah nol atau $\sum x=0$ itu sudah ketetapan dalam perhitungan menggunakan Metode Least Square. Maka perhitungannya untuk ketiga kota tersebut dapat dilihat pada tabel sebagai berikut:

Tabel 4.5 Perhitungan Mencari Trend Linear Kota Pandeglang Tahun 20122016

\begin{tabular}{|c|c|c|c|c|}
\hline $\begin{array}{c}\text { Tahu } \\
\mathrm{n}\end{array}$ & $\begin{array}{c}\text { Penjuala } \\
\mathrm{n}(\mathrm{Y})\end{array}$ & $\begin{array}{c}\mathrm{X} \\
\text { (Waktu } \\
\text { ) }\end{array}$ & $\mathrm{XY}$ & $\mathrm{X}^{2}$ \\
\hline $\begin{array}{c}2012- \\
2013\end{array}$ & 48.113 & -2 & $\begin{array}{c}96.22 \\
6\end{array}$ & 4 \\
\hline $\begin{array}{c}2013- \\
2014\end{array}$ & 48.185 & -1 & $\begin{array}{c}48.18 \\
5\end{array}$ & 1 \\
\hline $\begin{array}{c}2014- \\
2015\end{array}$ & 48.299 & 0 & 0 & 0 \\
\hline $\begin{array}{c}2015- \\
2016\end{array}$ & 48.319 & 1 & $\begin{array}{c}48.31 \\
9\end{array}$ & 1 \\
\hline $\begin{array}{c}2016- \\
2017\end{array}$ & 48.487 & 2 & $\begin{array}{c}96.97 \\
4\end{array}$ & 4 \\
\hline$\sum$ & 241.403 & 0 & 882 & 10 \\
\hline
\end{tabular}

(Sumber: Pengolahan Sendiri dari berbagai Sumber)

Tabel 4.6 perhitungan mencari Trend Linear Kota Serang Tahun 2012-2016

\begin{tabular}{|c|c|c|c|c|}
\hline Tahun & $\begin{array}{c}\text { Penjualan } \\
(\mathrm{Y})\end{array}$ & $\begin{array}{c}\mathrm{X} \\
\text { (Waktu) }\end{array}$ & $\mathrm{XY}$ & $\mathrm{X}^{2}$ \\
\hline $2012-2013$ & 42.629 & -2 & -85.258 & 4 \\
\hline $2013-2014$ & 42.718 & -1 & -42.718 & 1 \\
\hline $2014-2015$ & 43.002 & 0 & 0 & 0 \\
\hline $2015-2016$ & 43.222 & 1 & 43.222 & 1 \\
\hline $2016-2017$ & 43.389 & 2 & 86.778 & 4 \\
\hline$\sum$ & 214.960 & 0 & 2.024 & 10 \\
\hline
\end{tabular}

(Sumber: Pengolahan Sendiri dari Berbagai Sumber)

Tabel 4.7 perhitungan mencari Trend Linear Kota Cilegon Tahun 2012-2016

\begin{tabular}{|c|c|c|c|c}
\hline Tahun & $\begin{array}{c}\text { Penjualan } \\
(\mathrm{Y})\end{array}$ & $\mathrm{X}$ (waktu) & $\mathrm{XY}$ & $\mathrm{X}^{2}$ \\
\hline $2012-2013$ & 40.727 & -2 & -81.454 & 4 \\
\hline $2013-2014$ & 40.833 & -1 & -40.833 & 1 \\
\hline $2014-2015$ & 41.040 & 0 & 0 & 0 \\
\hline $2015-2016$ & 41.150 & 1 & 41.150 & 1 \\
\hline $2016-2017$ & 41.270 & 2 & 82.540 & 4 \\
\hline$\sum$ & 205.020 & 0 & 1.403 & 10 \\
\hline
\end{tabular}

(Sumber: Pengolahan Sendiri dari Berbagai Sumber)

Mencari nilai a dan b untuk mengetahui persamaan linear $\mathrm{Y}^{\prime}=\mathrm{a}+\mathrm{bX}$ untuk kota Pandeglang dapat di lihat perhitungannya sebagai berikut:

$\mathrm{a}=\frac{\Sigma Y}{n}=\frac{241.403}{5}=48.281$

$\mathrm{b}=\frac{\sum X Y}{\sum X^{2}}=\frac{882}{10}=88,2$

Dari nilai a dan b di atas maka di peroleh persamaan trendnya selanjutnya kita bisa cari nilai-nilai trend untuk tiap tahunnya dengan melakukan subtitusi nilai X pada tahun yang akan di cari nilai-nilai trend. Dapat dilihat sebagai berikut:

$$
\begin{aligned}
& Y 2012-2013=48.281+88,2(-2)= \\
& 48.104 \\
& Y 2013-2014=48.281+88,2(-1)= \\
& 48.192 \\
& Y 2014-2015=48.281+88,2(0)= \\
& 48.281 \\
& Y 2015-2016=48.281+88,2(1)= \\
& 48.369 \\
& Y 2016-2017=48.281+88,2(2)= \\
& 48.457
\end{aligned}
$$

Mencari nilai a dan $b$ untuk mengetahui persamaan linear $Y^{\prime}=a+b x$ untuk kota Serang dapat di lihat perhitungannya sebagai berikut:

$$
\begin{aligned}
& \mathrm{a}=\frac{\sum Y}{n}=\frac{214.960}{5}=42.992 \\
& \mathrm{~b}=\frac{\sum X Y}{\sum X^{2}}=\frac{2.024}{10}=202,4
\end{aligned}
$$

Dari nilai a dan b di atas maka di peroleh persamaan trendnya Dapat dilihat sebagai berikut:

$$
\begin{aligned}
Y 2012 & =42.992+202,4(-2)=42.587 \\
Y 2013 & =42.992+202,4(-1)=42.789
\end{aligned}
$$




$$
\begin{aligned}
\text { Y2014 } & =42.992+202,4(0)=42.992 \\
\text { Y2015 } & =42.992+202,4(1)=43.194 \\
\text { Y2016 } & =42.992+202,4(2)=43.397
\end{aligned}
$$

Mencari nilai a dan $b$ untuk mengetahui persamaan linear $\mathrm{Y}^{\prime}=\mathrm{a}+\mathrm{bX}$ untuk Kota Cilegon dapat dilihat perhitungannya sebagai berikut:

$$
\begin{aligned}
& \mathrm{a}=\frac{\sum Y}{n}=\frac{205.020}{5}=41.004 \\
& \mathrm{~b}=\frac{\sum X Y}{\sum X^{2}}=\frac{1.403}{10}=140,3
\end{aligned}
$$

Dari nilai a dan $b$ di atas maka di peroleh persamaan trendnya Dapat dilihat sebagai berikut:

$$
\begin{aligned}
Y 2012 & =41.004+140,3(-2)=40.723 \\
Y 2013 & =41.004+140,3(-1)=40.864 \\
Y 2014 & =41.004+140,3(0)=41.004 \\
Y 2015 & =41.004+140,3(1)=41.114 \\
\text { Y2016 } & =41.004+140,3(2)=41.285
\end{aligned}
$$

Setelah di ketahui y' selama 5 tahun, kemudian dapat di buat Tabel 4.8 untuk kota Pandeglang sebagai berikut:

Tabel 4.8 Perbandingan Hubungan Barang Terjual dan Ramalan Penjualan untuk kota Pandeglang

\begin{tabular}{|c|c|c|}
\hline Tahun & $\mathrm{Y}$ (Realisasi) & $\mathrm{Y}^{\prime}$ (Forcasting) \\
\hline $2012-2013$ & 48.113 & 48.104 \\
\hline $2013-2014$ & 48.185 & 48.192 \\
\hline $2014-2015$ & 48.299 & 48.281 \\
\hline $2015-2016$ & 48.319 & 48.369 \\
\hline $2016-2017$ & 48.487 & 48.457 \\
\hline
\end{tabular}

(Sumber: Pengolahan sendiri dari berbagai sumber)

Tabel 4.9 Perbandingan hubungan Penjualan dan Ramalan Penjualan Untuk Kota Serang

\begin{tabular}{|c|c|c|}
\hline Tahun & Y (Realisasi) & $\mathrm{Y}^{\prime}$ (Forcasting) \\
\hline $2012-2013$ & 42.629 & 42.587 \\
\hline $2013-2014$ & 42.718 & 42.789 \\
\hline $2014-2015$ & 43.002 & 42.992 \\
\hline $2015-2016$ & 43.222 & 43.194 \\
\hline $2016-2017$ & 43.389 & 43.397 \\
\hline
\end{tabular}

(Sumber: Pengolahan Sendiri dari berbagai Sumber)

Tabel 4.10 Perbandingan Realisasi Penjualan dan Ramalan Penjualan Untuk Kota Cilegon

\begin{tabular}{|c|c|c|}
\hline Tahun & $\begin{array}{c}\mathrm{Y} \\
\text { (Realisasi) }\end{array}$ & $\mathrm{Y}^{\prime}$ (Forcasting) \\
\hline $2012-2013$ & 40.727 & 40.723 \\
\hline $2013-2014$ & 40.833 & 40.864 \\
\hline $2014-2015$ & 41.040 & 41.004 \\
\hline $2015-2016$ & 41.150 & 41.114 \\
\hline $2016-2017$ & 41.270 & 41.285 \\
\hline
\end{tabular}

(Sumber: Pengolahan Sendiri dari berbagai Sumber)

Dalam Y' adalah nilai Trend (forcasting) a bilangan konstan, dengan $b$ Slope atau kofisien kecodongan garis trend $\mathrm{X}$ mewakili waktu jika di gambarkan, garis Trend di bawah ini untuk melihat garis trend penjualan Aktual dan garis trend nya untuk lebih memudahkan dalam menganalisis data penjualan. Dalam hal ini $\mathrm{Y}^{\prime}$ merupakn nilai Trend sedangkan $\mathrm{Y}$ merupakan nilai asli yang diperoleh. Tahun biasanya menunjukan variabel $\mathrm{X}$ Seperti terlihat pada Gambar 4.1 untuk kota Pandeglang berikut ini:

\section{Pola Trend}

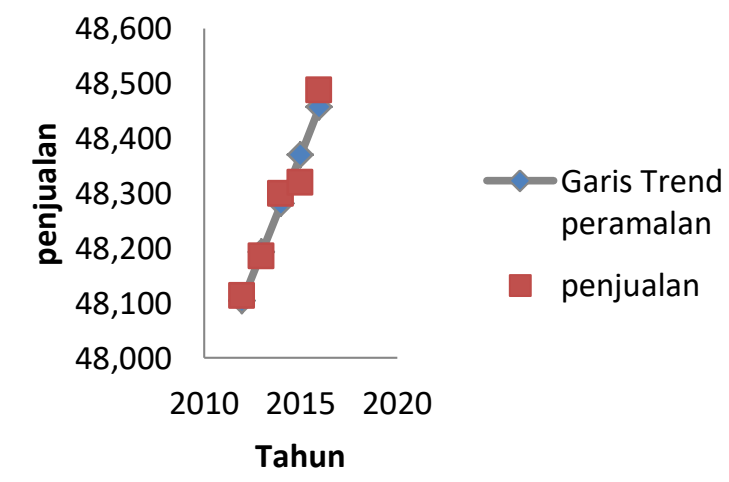

Gambar 4.1 Garis Trend dan Data penjualan Asli

(Sumber:

Pengolahan Sendiri dari berbagai Sumber)

Untuk melihat pola trend untuk kota Serang dapat dilihat pada Gambar 4.2 sebagai berikut: 


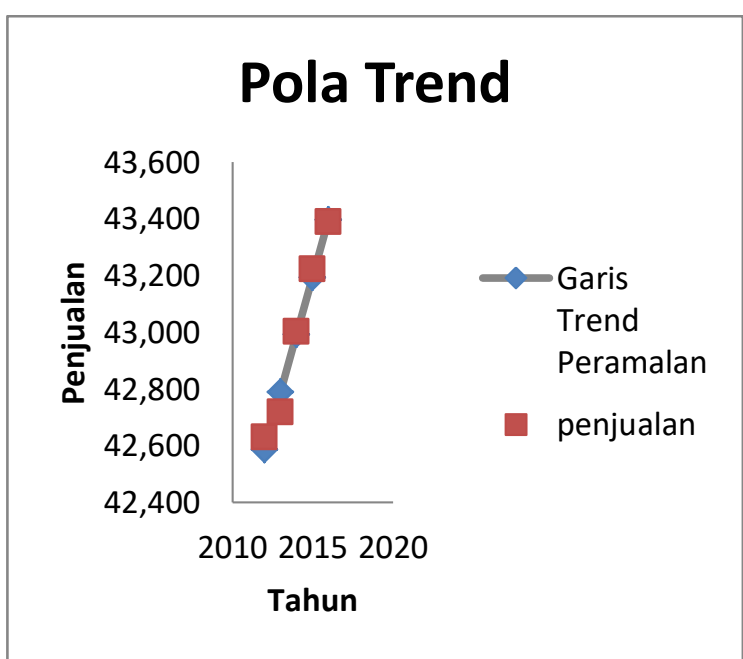

Gambar 4.2 Garis Trend dan Data penjualan Asli

(Sumber: Pengolahan Sendiri dari berbagai Sumber)

Bentuk Pola trend untuk kota Cilegon dapat dilihat pada Gambar 4.3

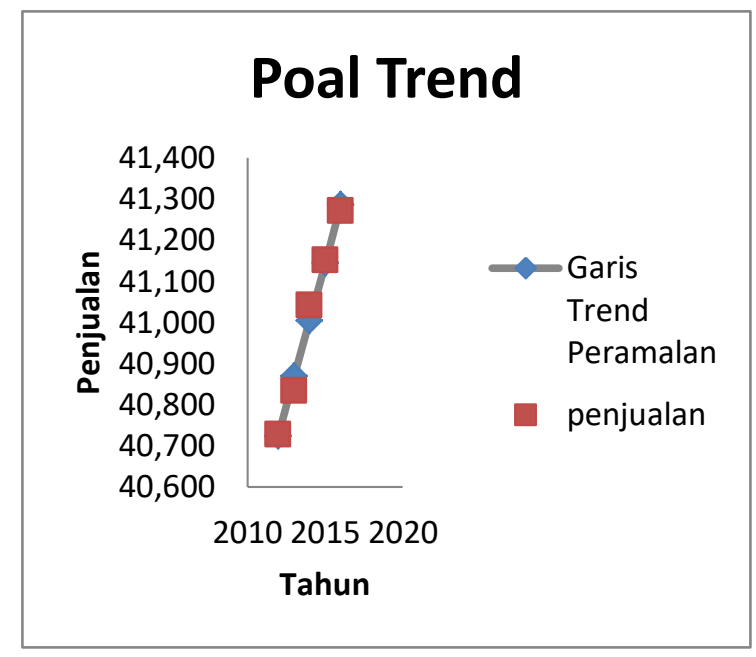

Gambar 4.3 Garis trend dan data penjualan Asli

(Sumber: Pengolahan Sendiri dari berbagai Sumber)

jika kita akan membuat forcasting untuk tahuntahun yang akan datang dapat di lihat hasil dari subtitusi nilai $X$ untuk tahun 2017 yaitu $X=3$ begitu seterusnya sampai berapa tahun data yang ingin di ramalkan berikut untuk meramalan penjualan buku di tahun 2017-2021 untuk kota Pandeglang, kota Serang dan Kota Cilegon secara berurutan sebagai berikut:

$\mathrm{Y} 2017-2018=48.281+88,2(3)=$ 48.546

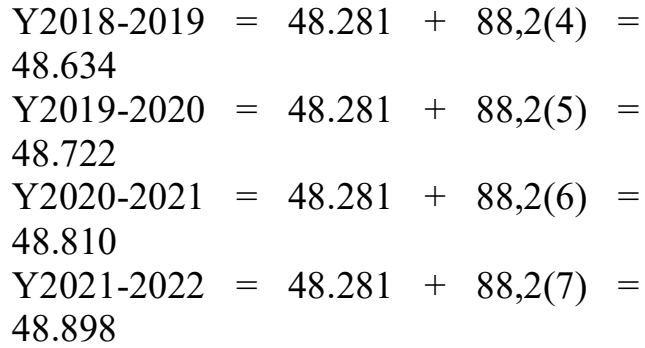

Perhitungan untuk kota Serang untuk meramalkan buku di tahun 2017-2021 sebagai berikut:

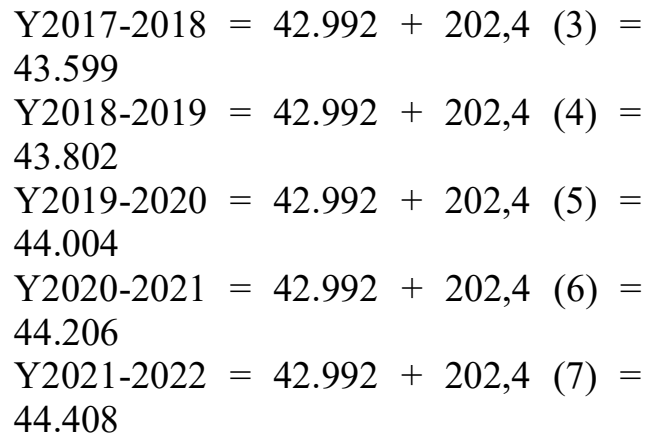

Perhitungan untuk kota Cilegon untuk meramalkan buku di tahun 2017-2021 sebagai berikut:

$\begin{aligned} & Y 2017-2018=41.004+140,3(3)=41.425 \\ & Y 2018-2019=41.004+140,3(4)=41.565 \\ & Y 2019-2020=41.004+140,3(5)=41.706 \\ & Y 2020-2021=41.004+140,3(6)=41.846 \\ & \text { Y2021-2022 }=41.004+140,3(7)=41.986\end{aligned}$

Dapat di simpulkan metode least square, seperti yang di ketahui mengandung kesalahan peramalan terkecil. Karena menurut garis trend peramalan sebelumnya sudah menunjukan pola trend yang sejajar atau garis lurus dengan data aktual penjualannya.

Jadi, data peramalan dengan menggunakan metode Least Square dapat menyimpulkan bahwa permintaan untuk 5 tahun kedepan dari ke tiga kota, dapat di ketahui dari hasil peramalan $\mathrm{di}$ atas perhitunganya sebagai berikut:

1. Penjualan Tahun 2017-2018: $48.546+$ $43.599+41.425=133.570$

2. Penjualan Tahun 2018-2019: $48.634+$ $43.802+41.565=134.001$

3. Penjualan Tahun 2019-2020 : 48.722+ $44.004+41.706=134.432$

4. Penjualan Tahun 2020-2021:48.810+ $44.206+41.846=134.862$

5. Penjualan Tahun 2021-2022 : $48.898+$ $44.408+41.984=135.292$ 
dari pernyataan tersebut untuk memudahkan pengelompokan datanya dapat di lihat pada Tabel 4.11 sebagai berikut:

Tabel 4.11 Hasil Peramalan Penjualan Buku untuk Setiap Tahun Periode Mendatang

\begin{tabular}{|c|c|}
\hline $\begin{array}{c}\text { Tahun } \\
\text { (dua semester) }\end{array}$ & $\begin{array}{c}\text { Penjualan Buku } \\
\text { (Examplar) }\end{array}$ \\
\hline $2017-2018$ & 133.570 \\
\hline $2018-2019$ & 134.001 \\
\hline $2019-2020$ & 134.432 \\
\hline $2020-2021$ & 134.862 \\
\hline $2021-2022$ & 135.292 \\
\hline
\end{tabular}

(Sumber: Pengolahan Sendiri dari berbagai Sumber)

\section{KESIMPULAN}

Dari hasil peramalan di atas peneliti ingin mengetahui perbedaan penjualan dari tiap-tiap kota yaitu Pandeglang, Serang, dan Cilegon berdasarkan tahun penjualan karena ingin mengetahui perbedaan penjualan dari setiap kota dari 5 tahun karena dengan mengetahui nilai signifikasinya untuk penjualan mendatang pun di asumsikan signifikasinya sama. Dalam hal ini penelitian menggunakan uji two way anova dua arah tanpa interaksi dalam pengujian ini mentiadakan sampel yang berkorelasi dengan dua faktor yang berpengaruh jadi pengujian hanya pada sampel yang lebih dari dua. Sebelum melakukan analisa harus terlebih dahulu mengetahui hipotesis nol dan hipotesis alternatif dari data tersebut hipotesis dapat di analisis sebagai berikut:

1. Apakah ada perbedaan penjualan buku dari tiap kota tersebut dalam beberapa tahun

2. Apakah ada perbedaan rata-rata penjualan buku untuk setiap tahun dari tiga kota.

Asumsi pertama yaitu:

H0 = Tidak ada perbedaan rata-rata penjualan masing-masing kota dalam lima tahun

$\mathrm{Ha}=$ ada perbedaan rata-rata penjualan masing-masing kota dala lima tahun

Asumsi dua yaitu:

$\mathrm{H} 0$ = Tidak ada perbedaan rata-rata penjualan pertahun dari tiga kota selama lima tahun
$\mathrm{Ha}=$ ada perbedaan rata-rata penjualan pertahun dari tiga kota selama lima tahun

1. Untuk memenuhi permintaan buku ke percetakan CV. Dunia Pustaka pada semester satu dan semester dua untuk 5 tahun kedepan adalah dari tahun 2017-2022 adalah $\quad 133.570$ examplar, 134.001 examplar, 134,432 examplar, 134.862 examplar, 135.292 examplar.

2. Untuk hipotesis anova dua jalur tanpa interaksi ini pernyataan sebagai berikut:

a. $\quad$ karena nilai $F_{1}$ hitung $=7.746,9>4,10$ maka $F_{1}$ hitung $>$ dari Ftabel artinya ada perbedaan rata-rata penjualan buku dari tiap kota tersebut dalam 5 tahun. Dalam hal ini berarti $\mathrm{HO}$ di tolak di karenakan ada perbedaan penjualan tiap kota dalam 5 tahun.

b. Karena nilai $F_{2}$ hitung $=17,126>3,33$ maka $F_{2}$ hitung $>$ dari $F$ tabel artinya ada perbedaan rata-rata penjualan buku dari setiap tahun dalam beberapa kota. Maka dalam hal ini Ho ditolak di karenakan ada perbedaan rata-rata penjualan buku dari setiap kota dalam beberapa tahun.

3. Untuk hasil uji paired sample t test pada ketiga kota tersebut dapat dilihat sebagai berikut:

a. Dalam output kita peroleh hasil korelasi antar kedua variabel sebelum dan sesudah, kita bisa lihat berapa hasil Correlation-nya, hasilnya untuk pandeglang sebesar 0,976 dengan nilai signifikasi $\mathrm{p}$ sebesar 0,004 . Artinya nilai $\mathrm{p}<0,05$. Selanjutnya untuk data Serang Correlation nya 0,990 dengan signifikasi 0,001 . Artinya nilai $\mathrm{p}<0$ : Dan untuk daerah Cilegon correlativin nya 0.994 dengan signifikasinya 0,001 artinya $\mathrm{p}<0,05$. Sehingga, ada hubungan signifikan untuk daerah sebelum dan sesudah peramalan. jika $r$ di kudratkan untuk daerah Pandeglang maka menunjukan pengaruh peramalan untuk lima tahun kedepan terhadap penjualan adalah $(0.976)^{2}=95 \%$ dan $5 \%$ di sebabkan faktor lain. Untuk Serang 98\% terdapat pengaruh peramalan dan $2 \%$ di sebabkan faktor lain, dan untuk Clegon $99 \%$ menunjukan pengaruh peramalan untuk lima tahun kedepan dan $1 \%$ di sebabkan faktor lain. 
b. Masing- masing kota dengan membandingan $\mathrm{t}$ hitung dan $\mathrm{t}$ tabel hasil akhir dari paired samples T test yaitu:

1) Kota Pandeglang: Jika -thitung < ttabel maka ada perbedaan volume penjualan dalam 5 tahun antara sebelum dan sesudah melakukan peramalan. Ternyata: $-31,809<-$ 2,776, maka H0 di tolak.

2) Kota Serang: Jika -thitung $<$-ttabel maka ada perbedaan volume penjualan dalam 5 tahun antara sebelum dan sesudah melakukan peramalan, Ternyata: $-49,685<-$ 2,776, maka H0 di tolak.

3) Kota Cilegon : Jika thitung $<$ ttabel ada perbedaan volume penjualan dalam 5 tahun antara sebelum melakukan peramalan dan sesudah peramalan. Ternyata: $-63.478<-$ 2,776, maka H0 di tolak.

Dalam hal ini hasilnya minus maka dalam salah satu tahun sebelum atau sesudah peramalan forcastingnya lebih kecil, dan dikarenakan data yang dioleh memiliki nilai yang besar maka hasil $t$ hitung pun besar nilainya.

\section{DAFTAR PUSTAKA}

Bagus. 2014. Sistem Informasi Peramalan Penjualan Kaos dengan Menggunakan Metode Least Square. Kediri: Distro MD 99.

Dana Sulistiyo Kusumo, Moch. Arief Bijaksana, Dhinta Darmantoro. Data Mining Dengan Algoritma Apriori Pada RDBMS Oracle,2003, Jurnal Penelitian dan Pengembangan Telekomunikasi, Juni 2003, Vol. 8 No. 1,3. Averson, Paul. 1998. "The Deming Cycle". The Balanced Scorecard Institute.

Gasperzs, 2005 . Penerapan metode trend moment dalam forecast penjualan motor yamaha di pt. Hasjrat abadi. Jurusan Teknik Informatika, Universitas Negri Gorontalo, Gorontalo, April 2013.

Kusrini, EmhaTaufiqLuthfi, "Algoritma Data Mining", Andi Yogyakarta, 2010
FeriSulianta \& Dominikus Juju, "Data Mining - MeramalkanBisnis Perusahaan", 2010 [2]. Dana Sulistiyo Kusumo, Moch. Arief Bijaksana, Dhinta Darmantoro. Data Mining Dengan Algoritma Apriori Pada RDBMS Oracle,2003,Jurnal Penelitian dan Pengembangan Telekomuniasi, Juni 2003, Vol. 8 No. 1,3

Kurniawan, Deni. 2008. Regresi Linier (Linear Regression), Jurnal, Foundation for Statistical Computing, Vienna, Austria

Muthia, Moh. Hidayat Koniyo, Manda Rohandi. 2013. Penerapan Metode Trend Moment dalam Forecast Penjualan Motor Yamaha. Gorontalo: PT. Hasjrat Abadi.

Montgomery, D. 2005. Design And Analysis Of Experiment 5th edition. John Willey and Sons. New York.

Mulyaningsih. 2005. Uji Kesesuaian Model. Repository IPB.

Makridakis dan Steven Wheelwright. 2010. Metode dan Aplikasi Peramalan, Jilid1. Penerbit : Binarupa Aksara Publisher. Tangerang-Indonesia.

Makridakis, S. dan Whellwright, S. C. 2005. Metode dan Aplikasi Peramalan. Binarupa Aksara. Jakarta. Nasution, A. H. 2008.

Rukmigarsari, E. 2011. Analisis Data dengan Program SPSS (Komputer 4). Malang: Universitas Islam Malang

Ruslan, Muhammad.2010. Rancangan Percobaan :Percobaan \& Rancangan Pengacakan \& Penataan Pola \& Model Rancangan Nilai Beda Rataan Telaah Data, ebook.

Rismawati, L. 2009. Analisis Sensitivitas Dari Persoalan Perbaikan Mesin Dalam Sistem Manufaktur. Perencanaan dan Pengendalian Produksi. Graha Ilmu. Yogyakarta.

Rekhi School of Information Technology Lusi, Shita Wardhani. 2007. Teknik 
Proyeksi untuk Bisnis dan Ekonomi, Edisi Pertama. Penerbit : BPFE, Yogyakarta.

Simarmata, Janner \& Paryudi, Imam. 2006. Basis Data, Andi Offset, Yogyakarta.

Swastha, Basu dan Irawan. 2008. Manajemen Pemasaran Modern. Penerbit: Liberty, Yogyakarta. 